\title{
Association Between Active or Passive Smoking and Allergic Rhinitis: an Evidence-Based Case Report
}

\author{
Lupita A. Reksodiputro, Thalia Mufida, Niken L. Poerbonegoro, \\ Mirta H. Reksodiputro* \\ Department of Otorhinolaryngology Head \& Neck \\ Faculty of Medicine Universitas Indonesia/dr. Cipto Mangunkusumo Hospital, Jakarta \\ *Corresponding author: citamirta@yahoo.com \\ Received 21 December 2020; Accepted 19 March 2021 \\ DOI: 10.23886/ejki.9.22.
}

\begin{abstract}
This evidence-based case report (EBCR) aims to investigate the association between active or passive smoking with allergic rhinitis by summarizing existing studies on the topic. A literature search was done on major databases with keywords related to this study's research question. The literature was appraised using CEBM University of Oxford for etiology study and systematic review sheets. The search obtained two articles for critical appraisal, includes a meta-analysis and a cohort study. The studies were appraised as valid, important, and applicable to the writer's setting. Saulyte et al' $s^{2}$ article described $R R$ active smoking with allergic rhinitis of $1.02(95 \% \mathrm{Cl}$ 0.92-1.15), with no significant association. They resolved the heterogeneity by making subgroups. The cross-sectional subgroup with $R R 1.09(95 \% \mathrm{Cl} 1.06-1.12)$ is statistically significant. There was a significant association in passive smoking and obtained $R R 1.10(95 \% \mathrm{Cl} 1.06-1.15)$. In the study by Mlinaric et al ${ }^{4}$ the $R R$ of active and passive smoking compared to non-smoker are 1.82 and 2.00; both show statistical significance. Both active and passive smoking is associated with a high risk of allergic rhinitis in adults and children.
\end{abstract}

Keywords active smoking, passive smoking, allergic rhinitis.

\section{Hubungan Perokok Aktif dan Pasif dengan Rhinitis Alergi: Laporan Kasus Berbasis Bukti}

\begin{abstract}
Abstrak
Pada laporan kasus berbasis bukti ini bertujuan untuk menginvestigasi hubungan antara perokok aktif dan perokok pasif pada pasien dengan rinitis alergi. Dilakukan pencarian literatur menggunakan kata kunci yang berhubungan dengan kasus pada beberapa search engine, kemudian dilakukan penilaian kelayakan dengan lembar appraisal dari CEBM University of Oxford for etiology study and systematic review sheet. Dari pencarian didapatkan dua artikel yang mepresentasikan kasus tersebut, yaitu studi meta analisis dan studi cohort. Studi meta analisis oleh Saulyte et al ${ }^{2}$ menyatakan RR pada perokok aktif dengan rinitis alergi adalah $1,02(95 \% \mathrm{Cl}$ 0,92-1,15). Pada subgrup potong lintang didapatkan perbedaan bermakna dengan RR 1,09 $(95 \% \mathrm{Cl}$ 1,06-1,12). Pada studi cohort oleh Minaric et al didapatkan RR pada perokok aktif 1,82 dan pada perokok pasif 2,00, keduanya menunjukan angka yang signifikan. Pada perokok aktif dan pasif berhubungan dengan risiko tinggi pada rinitis alergi di pasien dewasa dan anak-anak.
\end{abstract}

Kata kunci: perokok aktif, perokok pasif, rhinitis alergi. 


\section{Introduction}

Allergic rhinitis is an immunologically mediated symptomatic disease that affects $10-20 \%$ of the global population. Worldwide prevalence of allergic rhinitis increases in the last decade. The possible explanation is due to changing exposure to tobacco smoke. Several studies have investigated the relationship between tobacco smoke exposure to allergic disease, and whether smoking causes allergic rhinitis remains inconclusive., ${ }^{1,2}$

Despite increasing campaigns about the danger of smoking, active or passive smoking rates still increases worldwide. It is estimated more than a third of the global population is passive daily passive smokers; most of them were children who were exposed to tobacco smoke at home. ${ }^{3}$ The aim of this evidence-based case report (EBCR) is to analyze the association between active or passive smoking with the incidence of allergic rhinitis and compare the risk of allergic rhinitis in active or passive smokers in children and adults.

\section{Case Illustration}

Thirty-nine years old male patient came with his six years old son. They both experienced sneezing, runny and itchy nose, breathing through the mouth, and did not complain of any pain. These symptoms had occurred throughout the year, especially in the morning. The father already underwent a skin prick test and was diagnosed with allergic rhinitis, and symptoms had disappeared after two years of treatment. At the moment, they both experienced these symptoms two days a week. The father had no sleep disturbance and impairment of daily activities. However, the child experienced sleep disturbance. The father was an active tobacco smoker for more than ten years. The father intensely rubbed his nose, and his nasal mucosa looked pale. His son showed persistent mouth breathing, allergic shiners, nasal mucosa was livid with serous secretion, and postnasal drip. The father was diagnosed with mild intermittent allergic rhinitis and his son of moderate-severe intermittent allergic rhinitis. Based on the case illustration, the clinical question formulation: is there any association between active or passive smoking and allergic rhinitis in adults and children?

\section{Evidence Research Strategy}

Articles search through PubMed and Cochrane was conducted on June $18^{\text {th }}, 2020$, to identify all potentially eligible studies using keywords relevant to the clinical question. The search retrieved 1722 papers in both databases. The result was sorted by inclusion and exclusion criteria resulting in 53 eligible studies for abstract screening. All abstracts were screened, a large majority of the articles were excluded because through abstract screening, the articles were not suitable to answer the clinical question (Figure 1). Critical appraisal for relevance and validity yielded two articles; studies by Saulyte et $\mathrm{al}^{2}$ and Mlinaric et $\mathrm{al}^{4}$ provided sufficient data and are usable in answering the clinical question.

\section{Results}

The study by Saulyte et $\mathrm{al}^{2}$ entitled "Active or Passive Exposure to Tobacco Smoke and Allergic Rhinitis, Allergic Dermatitis, and Food Allergy in Adults and Children: a systematic review and metaanalysis." The papers included 196 studies, and 97 of them discussed allergic rhinitis. Another study is "Passive Smoking and Respiratory Allergies in Adolescents" by Mlinaric et al. ${ }^{4}$ Saulyte et $\mathrm{al}^{2}$ presented heterogeneity on active or passive smoking for allergic rhinitis and an asymmetry funnel plot for active smoking and the impact of allergic rhinitis. The considerable amount of heterogeneity is due to a difference in design, case, and exposure definitions and adjustment. The authors analyze the data by making subgroups based on study design and age to address the heterogeneity. For the publication bias of active smoking, Egger's test yielded a non-significant ( $p$-value $=0.27$ ), and it is confirmed that no there is no missing data 


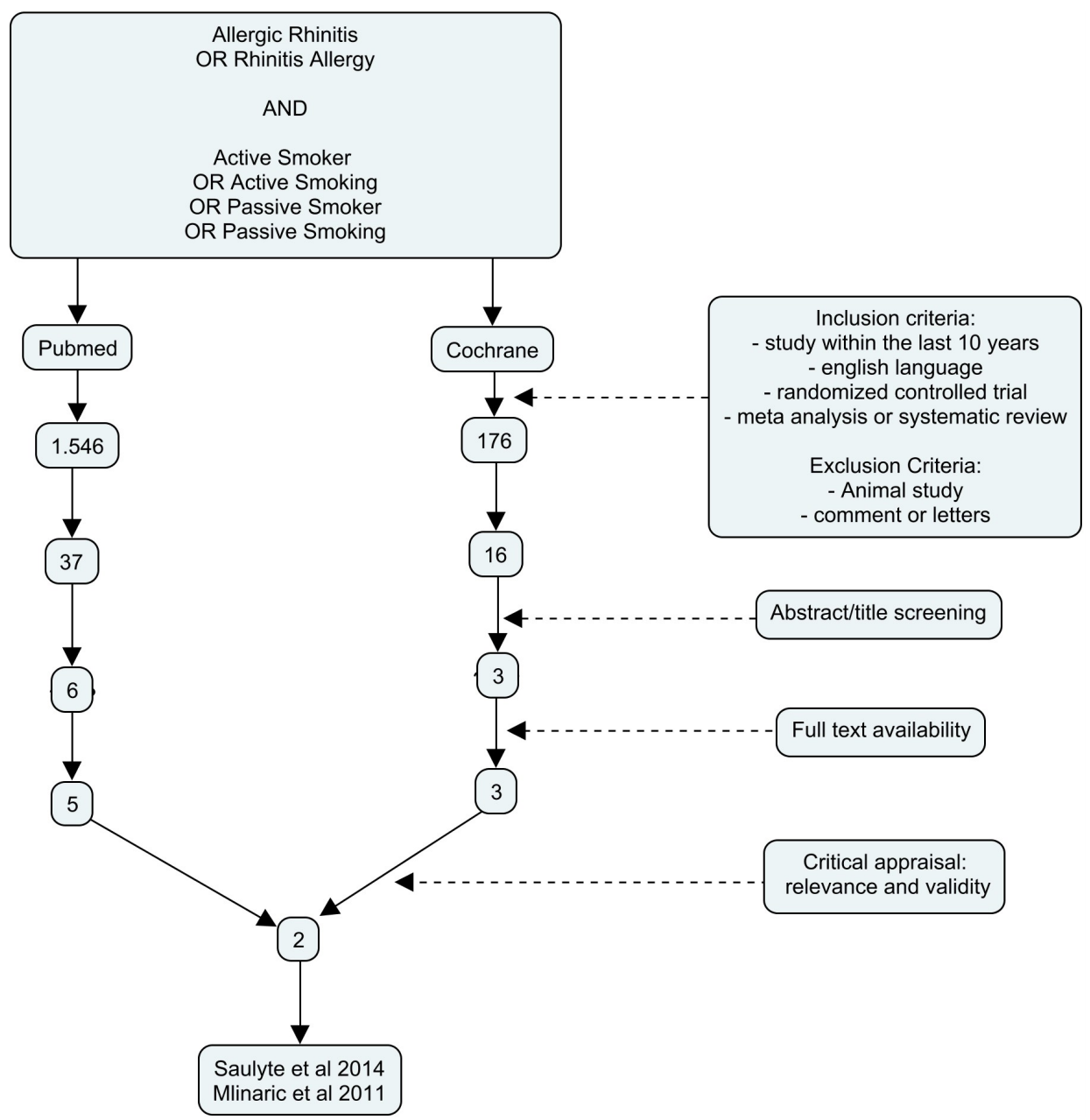

Figure 1. Literature Search Strategy

The study by Mlinaric et $\mathrm{al}^{4}$ investigates the impact of active or passive exposure to smoke and allergic condition on IgE levels and allergic disease diagnosis. The study consisted of 155 adolescents consisting of non-smokers, active smokers, and passive smokers. The smoking habit was examined through a survey, the physician confirmed the diagnosis of asthma and rhinitis, and the IgE levels were counted using the ELISA method. The result is presented with $X 2, p$-value, and the geometric mean for the IgE level. The results of both studies are presented in Table 1. Critical appraisal results for both studies are described in Table 2 and Table 3.

\section{Discussion}

Allergic rhinitis is a common disease but still always an exciting topic to discuss from the epidemiology, etiology, diagnosis, and treatment points. Sea Allergy Forum Effective Management of Allergic Rhinitis 2020 stated that allergic rhinitis's primary etiology is from the air. It can be polluted air, pollen, and exposure to environmental tobacco smoke. So the number could be determined by the prevalence of active or passive smoking in the population. Worldwide, $14 \%$ of adolescents aged 13-15 are active smokers, with countries reaching a prevalence of $40 \%$ and more than one-third of children live with at least one adult smoker. ${ }^{2}$

Tobacco smoke contains many toxic substances and pro-inflammatory effects. It may precipitate allergic sensitization in two different ways, direct and indirect. The first way, tobacco smoke directly affecting IgE production on the cellular level. ${ }^{6-8} \mathrm{Kim}$ et $\mathrm{al}^{7}$ study showed that the increase of total IgE level was correlated with a cumulative smoking exposure and the elevated total $\operatorname{lgE}$ level associated with the increased risk of sensitization to common allergy. ${ }^{7}$ The second way is the indirect pathway by increasing the permeability of respiratory epithelium and reducing its protective barrier; therefore, the pathogenesis of allergic rhinitis from tobacco smoking remains inconclusive. 
Table 1. The Result of All Studies

\begin{tabular}{|c|c|c|c|}
\hline Author & Exposure & Results RR (95\% Cl) & Summary \\
\hline $\begin{array}{l}\text { Saulyte et } \text { al }^{2} \\
\text { Systematic } \\
\text { review, } 97 \\
\text { studies for AR, } \\
139 \text { studies in } \\
\text { total }\end{array}$ & $\begin{array}{l}\text { The study explained both } \\
\text { active and passive exposure } \\
\text { to tobacco smoking, but } \\
\text { the duration and amount of } \\
\text { exposure were still unclear. } \\
\text { This study also discussed } \\
\text { the impact on dermatitis } \\
\text { allergy and food allergy, but } \\
\text { not discussed in this study. }\end{array}$ & 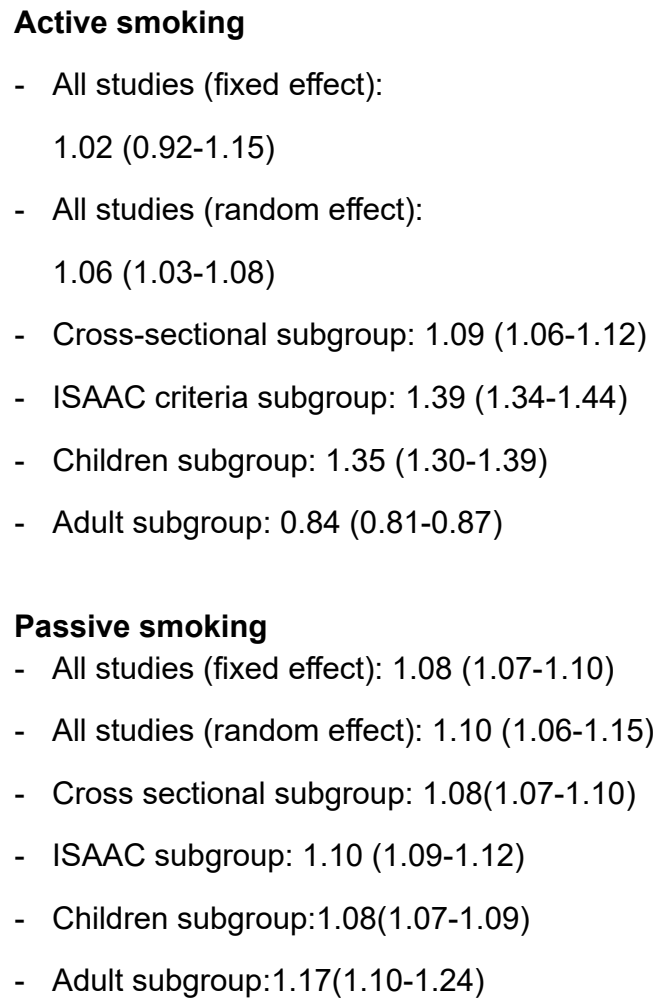 & $\begin{array}{l}\text { The study's risk result } \\
\text { is higher due to the } \\
\text { increased number of } \\
\text { patients, differences } \\
\text { in designs, case, and } \\
\text { exposure definition } \\
\text { and adjustment. }\end{array}$ \\
\hline $\begin{array}{l}{\text { Mlinaric et } \text { al }^{4}} \\
\text { A retrospective } \\
\text { cohort study, } 155 \\
\text { samples }\end{array}$ & $\begin{array}{l}\text { The study consisted of } \\
155 \text { adolescents, including } \\
31 \text { active smokers, } 60 \\
\text { passive smokers, and } 64 \\
\text { non- smokers. The subjects } \\
\text { undergo total and specific } \\
\text { IgE antibody examination. } \\
\text { Physician previously } \\
\text { confirmed allergy diagnosis } \\
\text { (asthma and AR) }\end{array}$ & $\begin{array}{l}\text { Active smoking } \\
\text { - } \quad \text { RR } 1,82, x^{2} 4.45, \text { p } 0.034 \\
\text { - } \quad \text { Total lgE level: } 53,67 \mathrm{IU} / \mathrm{ml} \\
\text { - Mean smoking exposure } 1.69 \pm 1.79 \text { years }\end{array}$ & $\begin{array}{l}\text { Clinical manifestation } \\
\text { of allergic disease is } \\
\text { more frequent in an } \\
\text { active and passive } \\
\text { smoker than in a non- } \\
\text { smoker. } \\
\text { Total IgE level is } \\
\text { significantly higher in } \\
\text { a passive smoker than } \\
\text { the active smoker }\end{array}$ \\
\hline
\end{tabular}

${ }^{*} \mathrm{RR} ;{ }^{* *}$ Relative Risk

Table 2. Critical Appraisal of Systematic Review from Saulyte et al ${ }^{2}$ in 2014

\begin{tabular}{|c|c|c|c|c|c|}
\hline \multicolumn{6}{|c|}{ Validity } \\
\hline PICO & $\begin{array}{l}\text { Appropriate } \\
\text { searching }\end{array}$ & $\begin{array}{l}\text { Relevant study } \\
\text { included }\end{array}$ & $\begin{array}{c}\text { Quality } \\
\text { assessment of } \\
\text { trials }\end{array}$ & Heterogeneity & $\begin{array}{l}\text { Level of } \\
\text { evidence }\end{array}$ \\
\hline+ & + & + & + & + & $1 \mathrm{~A}$ \\
\hline
\end{tabular}

These two articles include one meta-analysis and one cross-sectional study. There were two different study designs, so the total number of samples and data processing were also different. Saulyte et al, ${ }^{2}$ reported a systematic review and meta-analysis study, 196 studies, published in
139 articles and carried out in 51 countries. They found 97 studies on allergic rhinitis, 91 on allergic dermatitis, and eight on food allergy. Of the 97 studies, 34 studies on active smoking and 63 studies on passive smoking. Mlinaric et $\mathrm{al}^{4}$ did a cross-sectional study about the impact of active or 
passive exposure to smoke and allergic condition on $\lg E$ levels and diagnosis of allergic disease. The study consisted of 155 adolescents: 64 nonsmokers, 31 active smokers, and 60 passive smokers. The smoking habit was examined through an interview with questions about the duration of smoking and the number of cigarettes consumed per day. The diagnosis of asthma and rhinitis was confirmed previously and the IgE levels were counted from the venous blood sample using the ELISA method. The result is presented with $X 2$, $p$-value, and the geometric mean for the IgE level.

Overall, Saulyte et $\mathrm{al}^{2}$ reported no significant difference in active smoking with allergic rhinitis (RR $1.02 ; 95 \% \mathrm{Cl} 0.92-1.15)$. The relative risk for allergic rhinitis in the active smoking group is 1.02 times higher than in the non-smoking group. This result is deemed non-significant by looking at the confidence interval, which ranges between 0.92-1.15. This result can be affected by the data heterogeneity. To eliminate heterogeneity, Saulyte et $\mathrm{al}^{2}$ analyze the data in subgroups defined by study design and age of participants. Cross-sectional subgroups with RR $1.09(95 \% \mathrm{Cl} 1.06-1.12)$ are statistically significant in study design subgroups. ${ }^{2}$ In subgroups analysis based on participants age, children and adolescent showed the RR is $1.4(95 \% \mathrm{Cl} 1.24-1.59)$ for active smoking and $1.09(95 \% \mathrm{Cl} 1.04-1.14){ }^{2}$

Mlinaric et $\mathrm{al}^{4}$ presented the data of allergic diseases with $X 2$, so we converted the data to $R R$ for this study. The RR of active smokers compared to non-smokers was 1,82 and is statistically significant. On the other hand, passive smokers' RR compared to non-smoker is 2.007 and shows statistical significance. ${ }^{6}$ We also count the number needed to harm, wherein the active smoker group, the number needed to harm is four, and in the passive smoker group, the number needed to harm is 5 . Both groups experience significantly higher allergic conditions compared to non-smoker. Smoke can precipitate allergic conditions by directly influencing the release of $\operatorname{lgE}$ or increasing permeability of respiratory epithelium that causes other allergens' entry.

Determination of diagnosis is essential. Studies that used the standardized ISAAC criteria showed a statistically significant number, RR $1.5(95 \% \mathrm{Cl}$ 1.35-1.66), two but not on those studies that used their protocols. Mlinaric et $\mathrm{al}^{4}$ did not mention the diagnostic tools used to diagnose allergic rhinitis since physicians previously made the diagnosis, but to examine further the effect of smoke on the allergic disease, they used IgE measurements.

$\lg \mathrm{E}$ synthesis is regulated by IL-2, IL-4, and gamma interferon. Active or passive smoking increases IgE levels through a similar mechanism and the stimulation of IL-4.,9 $\mathrm{lgE}$ levels are the highest in passive smoking groups compared to active smokers and non-smoker, which may be due to the exposure duration. In the study, the mean smoking duration for active smokers was 1.69 (1.79 years, and the mean period of passive smokers' exposure was $16.18 \pm 2.20$ years. Smoking duration has a cumulative effect on IgE level and allergic sensitization. ${ }^{6}$ These results suggest that exposures to active or passive tobacco smoking are associated with a modest increase in allergic rhinitis risk. However, so many factors influence the result. Saulyte et $\mathrm{al}^{2}$ showed no significant result, especially for the children and adolescent subgroup. This result related to the "atopic march" concept suggests that the sequences tend to remission later in life. ${ }^{2,9}$

Table 3. Appraisal of Etiologic Study from Mlinaric et $\mathrm{al}^{4}$ in 2011

\begin{tabular}{|c|c|c|c|c|c|c|c|c|c|c|c|c|c|c|c|}
\hline \multirow[b]{3}{*}{$\begin{array}{l}\frac{5}{5} \\
\frac{0}{0} \\
0 \\
\frac{0}{0} \\
\text { के }\end{array}$} & \multirow[b]{3}{*}{ 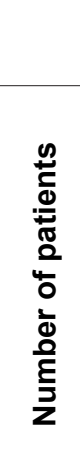 } & \multirow[b]{3}{*}{ 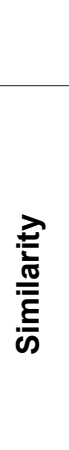 } & \multirow[b]{3}{*}{ 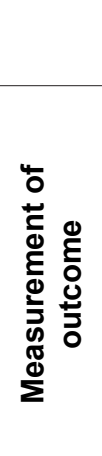 } & \multirow[b]{3}{*}{$\begin{array}{l}\text { 윽 } \\
3 \\
\text { o } \\
\overline{0}\end{array}$} & \multicolumn{5}{|c|}{ lalidity } & \multicolumn{2}{|c|}{$\begin{array}{c}\text { Importance } \\
\text { (RR) }\end{array}$} & \multicolumn{4}{|c|}{ Applicability } \\
\hline & & & & & \multicolumn{5}{|c|}{ Diagnostic } & \multirow[b]{2}{*}{ 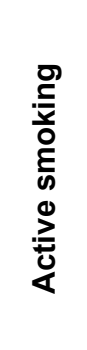 } & \multirow[b]{2}{*}{ 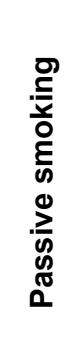 } & \multirow[b]{2}{*}{ 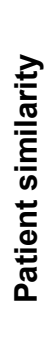 } & \multirow[b]{2}{*}{$\frac{I}{z}$} & \multirow[b]{2}{*}{ 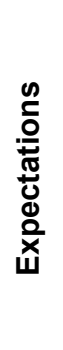 } & \multirow[b]{2}{*}{ 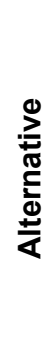 } \\
\hline & & & & & 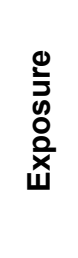 & 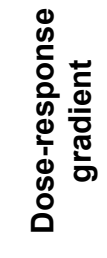 & 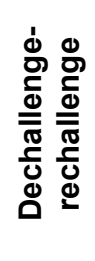 & $\begin{array}{l}\text { dे } \\
\frac{c}{0} \\
\frac{\Delta}{0} \\
\frac{0}{0} \\
0 \\
0\end{array}$ & 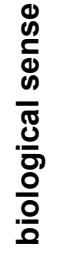 & & & & & & \\
\hline CS & 155 & + & + & - & $\mathrm{N} / \mathrm{A}$ & $\mathrm{N} / \mathrm{A}$ & $\mathrm{N} / \mathrm{A}$ & + & + & 1.82 & 2.00 & + & $4-5$ & + & + \\
\hline
\end{tabular}

+ , yes (mentioned explicitly in the article); -, no (mentioned explicitly in the article); N/A, not mentioned in the article. Abbreviations: CS; cross-sectional, NNH; number needed to harm 
The study by Mlinaric et al ${ }^{4}$ is a cross-sectional design that cannot show the disease progression and the effect of smoking duration on the disease and the relationship between smoking quantity and duration to IgE level. Saulyte et $\mathrm{al}^{2}$ reported various types of studies, sample variants, and exposure, thus producing heterogeneity, making it difficult to determine the amount of exposure that affects allergic rhinitis. The exposure of groupings, such as duration and number, is also necessary to see the impact of allergic rhinitis.

\section{Conclusion}

With a high risk of allergic rhinitis in adults and children. Passive smokers have higher $\lg \mathrm{E}$ and a higher risk of allergic rhinitis due to longer exposure duration and more common in children. The role of physicians is essential in increasing awareness of health risks associated with smoking. Children are vital, as both active or passive exposure to tobacco smoke has been implicated in the development of "atopic march." Future studies should reduce the bias possibilities and heterogeneity.

\section{References}

1. Klimek L, Bachert C, Pfaar O, Becker S, Bieber T, Brehler $\mathrm{R}$ et al. ARIA guideline 2019: treatment of allergic rhinitis in the German health system. Allergol Select. 2019;3(01);22-50
2. Saulyte J, Regueira C, Montes-Martínez A, Khudyakov P, Takkouche B. Active or passive exposure to tobacco smoking and allergic rhinitis, allergic dermatitis, and food allergy in adults and children: a systematic review and meta-analysis. PLoS Medicine. 2014;1: e1001611

3. Nadhiroh S, Djokosujono K, Utari D. The association between secondhand smoke exposure and growth outcomes of children: a systematic literature review. Tob Induc Dis. 2020;18:12

4. Mlinaric A, Popopvic GS, Nadalin S, Skuria B, Munivrana $\mathrm{H}$, Milosevic $M$. Passive smoking and respiratory allergies in adolescent. Eur Rev Med Pharmacol Sci. 2011;15: 973-7

5. Soo KY, Yeon KH, Ahn HS, Soe ST, Yen SJ et al. The association between tobacco smoke and serum immunoglobulin E levels in Korean adults. Intern Med. 2017;56: 2571-77

6. Strzelak A, Ratajczak A, Adamiec A, Feleszko W. Tobacco smoke induces and alters immune responses in the lung triggering inflammation, allergy, asthma and other lung diseases: a mechanistic review. Int J Environ Res Public Health. 2018;15(5); 1033

7. Accordini S, Janson C, Svanes C, Jarvis D. The role of smoking in allergy and asthma: lessons from the ECRHS. Curr Allergy Asthma Rep. 2012;12:185-91.

8. Fernandes $\mathrm{S}$, Andrade C, Caminhas A, Camargos $P$, Ibiapina C. Prevalence of self-reported smoking experimentation in adolescents with asthma or allergic rhinitis. J Bras Pneumol. 2016;42(2): 84-7

9. Hill D, Spergel J. The atopic march. Ann Allergy Asthma Immunol. 2018;120(2): 131-7 